\title{
EBEVEYNLERI BOŞANMA SÜRECINDE OLAN 9-12 YAŞ \\ GRUBUNDAKI ÇOCUKLARIN BOŞANMAYA UYUM DÜZEYLERININ INCELENMESI
}

\section{THE STUDY OF THE 9-12 YEARS OLD CHILDREN'S LEVEL OF ADJUSTMENT TO DIVORCE WHOSE PARENTS IN THE DIVORCE PROCESS}

\author{
BIm.Uzm. Okan AYDIN \\ Prof.Dr. Gülen BARAN ${ }^{2}$
}

\begin{abstract}
ÖZET
$\mathrm{Bu}$ çalışma ebeveynleri boşanma sürecinde olan dokuz-on iki yaş grubundaki çocukların boşanmaya uyum düzeylerinin değerlendirilmesi ve uyumda etkili olabilecek etmenlerin belirlenmesi amacıyla yapılmıştır. Araştırmaya Ankara Adalet Sarayı'nda bulunan on bir aile mahkemesinde boşanma davaları devam eden doksan üç çiftin, dokuz-on iki yaş grubunda bulunan çocukları (55 kız-38 erkek) dahil edilmiştir. Araştırmada "Çocuk Bilgi Formu" ve "Çocuklar İçin Boşanmaya Uyum Ölçeği" kullanılmıştır. Araştırma sonucunda; çocukların boşanmaya uyumunda doğum sırasının anlamlı farklılığa sebep olduğu belirlenirken, çocukların cinsiyetinin, kardeş sayısının, anne-baba ayrılığını öğrendiği kişinin, birlikte yaşadığı ebeveynin, anne-babanın öğrenim düzeyinin, çalışma durumunun ve çocuk için profesyonel yardım alınmasının anlamlı bir farklııı yaratmadığı saptanmıştır.
\end{abstract}

Anahtar Kelimeler: Boşanma, velayet, boşanmaya uyum

\section{ABSTRACT}

The aim of this study was to investigate children adjustment level of divorce between the ages of nine-twelve whose parents in the divorce process, beside this find out the factors which can be effective. The sample of the study had been drawn from ninety three children (55 girls-38 boys) between the ages of nine and twelve whose parents divorce process have been continuing at eleven family courts in Ankara. "Children Information Form" and "The Children's Divorce Adjustment Inventory (CDAI)" had been used in the study. According to the results of the study it is found that birth

\footnotetext{
${ }^{1}$ Ankara 2. Aile Mahkemesi, okanydn@hotmail.com

${ }^{2}$ Ankara Üniversitesi Sağlık Bilimleri Fakültesi Çocuk Gelişimi Bölümü, e-posta barangln@gmail.com
} 
order of children have significant effect on children's level of adjustment to divorce, on the other hand childrens' gender, number of siblings, the person informing about the divorce, who parents living together, parents' level of education, employment status and professional help for children have no significant effect on children's level of adjustment to divorce.

Key Words: Divorce, guardianship, adjustment to divorce

\section{GíRiş}

Sanayi ve bilgi toplumlarında boşanma, feodal kuralların hakim olduğu toplumlara göre daha yaygın ve daha yüksek oranlardadır. Boşanma sadece gerçekleştiği aileyi ve onun üyelerini değil, doğurduğu sonuçlar ile tüm toplumu etkilemesi nedeniyle önemle üzerinde durulması gereken konulardan birisidir. Boşanma sonucunda aile parçalanma sürecine girmekte, aile içindeki yetişkinler ve varsa çocuklar sosyal destek sistemlerinden yeterince destek görememeleri durumunda boşanma sürecinde ve sonrasında psikolojik, duygusal ve mental boyutta çeşitli sorunlar ile karşı karşıya kalmaktadır (Benedek ve Brown, 1997). Boşanmanın çocuklar açısından ortaya çıkarabileceği kimi sorunlar; korku, üzüntü, öfke, suçluluk, yalnızlık, reddetme, uyku problemleri, kendi kendini tatmin, okul problemleri, psikolojik ve fiziksel hastalıklar, yemek yeme problemleri olarak belirtilebilmektedir (Öztürk, 2008). Çocuğun sorunlar ile başa çıkabilmesi için bunları dışa vurması ve sorunların farkına varan ebeveynlerin uygun sorun çözme yöntemlerini, profesyonel destek de alarak sağlamaya çalışmaları gerekmektedir. Aksi takdirde zamanında çözülmeyen sorunların etkilerini uzun vadede göstermesi söz konusudur (Cohen, 2002; Yörükoğlu, 2003). Aile parçalanmasının çocuk üzerindeki olumsuz etkilerini artıran en önemli etken ebeveynlerin kendi duygu ve düşüncelerini ön plana alarak hareket etmeleridir (Hawkins vd., 1992).

Boşanmanın karmaşık yapısı, çocuklar üzerindeki etkisinin tam olarak anlaşılabilmesini zorlaştırmaktadır. Ancak ebeveynlerinin ayrılmasının çocuk üzerinde kısa ve uzun vadede farklı etkiler yaratması kaçınılmaz bir durumdur (Beardslee vd., 2003). Mechanic ve Hansell (1989) yaptıkları çalışmada, aile içinde yaşanan sorunların, çocuklarda depresif belirtilere yol açtığı ve buna bağlı olarak fiziksel rahatsızlıkların ortaya çıktığı sonucuna ulaşmışlardır. Özellikle boşanmanın gerçekleştiği ilk dönemde aile parçalanmasının çocuk üzerindeki olumsuz etkileri fazla olmaktadır. Bu dönemde çocuklar uygun olmayan sosyal şartların da etkisiyle regresif belirtiler 
gösterip, ebeveynlerini kaybetme ve yalnız kalma korkusu yaşamaktadır (Walzcak ve Burns, 2004).

Lengua (2000)' ya göre çocukların, ebeveynlerinin boşanmasını kabul etmelerinde ortaya çıkan zaman farklılıkları, anne-babanın yaşadıkları strese ve çocuğa bunu aktarma durumlarına bağlıdır. Salk (2002)'a göre boşanmış ailelerden gelen çocuklar fiziksel ve duygusal istismara daha açık olabilmekte, zamanlarını nitelikli kullanmanın aksine, boş zamanlarını kötü alışkanlıklar edinerek geçirebilmekte, yaşadıklarını kader olarak algılayıp, kaderci bir kişilik yapısı geliştirerek; yaşamları ile ilgili sorumluluk alamama, yönlendirilmeye açık olma ve özgüven eksikliği yaşama riski taşıyabilmektedirler.

Çocuk açısından ebeveynlerinin ayrılması stresli bir yaşantıyı beraberinde getirmektedir. Stres kaynakları çocuk için duygusal ve fiziksel boyutta sağlığın bozulması riskini ortaya çıkarmaktadır. Bu olumsuzlukların çocuk üzerindeki etkisi, çocuğun sahip olduğu koruyucu ve destekleyici faktörlere bağlıdır (Amato, 2000). Emery vd. (1999) çalışmalarında boşanmış ebeveynlerin çocuklarının daha fazla davranış problemi gösterme potansiyeli taşıdıklarını saptamış, ebeveynlerin evlilik durumlarının ve aile yapılarının çocukların davranışlarını etkileyen önemli etkenler olduğunu ortaya koymuşlardır. O'Connor vd. (2000) parçalanmış ailelerden gelen çocukların, daha fazla davranış problemi ve sosyal uyumsuzluk gösterdikleri bulgusuna ulaşmışlardır. Whiteside ve Becker (2000) boşanma sonrasında depresif belirtiler gösteren annelerin, çocuklarının davranış problemleri gösterdiklerini saptamışlardır.

Türkiye'de boşanmanın çocuklar üzerine etkilerini inceleyen çeşitli çalışmaların yapıldığı bilinmektedir. Ancak bu çalışmalarda daha çok boşanma nedeniyle çocukların yaşadığı depresyon (Aral ve Gürsoy, 2000; Korkut, 1990), kaygı (Aral ve Başar, 1998), nevrotik eğilim (Kuyucu, 1999), bağımlılık eğilimi (Baran ve Bütün Ayhan, 2004) ve benlik düzeyi (Öztürk, 2006) üzerinde durmuşlardır. İlgili literatürde ebeveynleri boşanma sürecinde olan çocukların boşanmaya uyum düzeylerini inceleyen bir çalışma bulunmamaktadır. $\mathrm{Bu}$ nedenle bu çalışmada ebeveynleri boşanma sürecinde olan çocukların boşanmaya uyumu; cinsiyet, doğum sırası, kardeş sayısı, çocukların anne-baba ayrılığını öğrendikleri kişi, birlikte yaşadığı ebeveynin kim olduğu, anne-babanın öğrenim, çalışma durumu ile çocuk için profesyonel yardım alınma durumu gibi değişkenler dikkate alınarak incelenmiştir. 


\section{MATERYAL VE YÖNTEM}

Araştırmanın evrenini; Ankara ilinde yaşayan, boşanma davaları devam eden, bu süreçte velayet ile ilgili anlaşmazlık içerisinde bulunan ebeveynlerin dokuz-on iki yaş grubundaki çocukları oluşturmaktadır. Araştırmaya Ankara Adalet Sarayı'nda bulunan on bir aile mahkemesinde boşanma davaları devam eden doksan üç çiftin, dokuz-on iki yaşları arasındaki doksan üç çocuğu (55 kız-38 erkek) dahil edilmiştir. Araştırmanın örneklemi oluşturulurken, çocukların sorulara cevap verebilmesi için zihinsel engellerinin bulunmamasına dikkat edilmiştir. Ayrıca çocukların araştırmaya gönüllü katıııı esas alınmış, boşanma sürecindeki ebeveynlerin dokuz- on iki yaş grubunda birden fazla çocuğu var ise tercihen büyük yaştaki çocuk araştırmaya dahil edilmiştir.

Araştırmada çocuklara ilişkin bilgileri elde etmek amacıyla araştırmacı tarafından hazırlanan "Çocuk Bilgi Formu" ve çocukların boşanmaya uyum düzeyini belirleyebilmek için "Çocuklar İçin Boşanmaya Uyum Ölçeği" kullanılmıştır.

Çocuk Bilgi Formu; çocuğun cinsiyeti, yaşı, doğum sırası, kardeş sayısı, ebeveynlerinin ayrılığını kimden öğrendiği, ayrılık sürecinde kiminle yaşadığı ve birlikte yaşamadığı ebeveyni ile olan ilişkileriyle ilgili soruları içermektedir.

Ebeveynleri boşanma sürecinde olan veya boşanmış dokuz- on iki yaş grubundaki çocukların boşanmaya uyum düzeylerini değerlendirmeyi amaçlayan Çocuklar İçin Boşanmaya Uyum Ölçeği (The Children's Divorce Adjustmet Inventory) Portes vd. (1999) tarafından geliştirilmiş, Arifoğlu (2006) tarafından geçerlik-güvenirlik çalışması yapılmıştır.

Toplam yirmi iki maddeden oluşan ölçekte çatışma- kötü uyum $(1,2,10,11,12,14,16,18,19,20,21$. madde), depresyon- anksiyete $(3,6,7,8,15,17$. madde) ve sosyal destek $(4,5,9,13,22$. madde) olmak üzere üç alt boyut bulunmaktadır. Ölçeğin değerlendirilmesi sonucunda, ölçeğin tümünden tek bir puan elde edilmektedir ve bu puan çocukların boşanmaya uyumunu göstermektedir. Herhangi bir kesim puanı olmayan ölçekten alınabilecek en düşük puan 22, en yüksek puan 110'dur. Alınan puan arttıkça çocuğun boşanmaya uyumunun arttığı sonucuna varılmaktadır (Arifoğlu, 2006).

Verilerin değerlendirilmesinde ebeveynleri boşanma sürecinde olan çocukların boşanmaya uyumunda ikili gruptan oluşan, çocukların cinsiyeti, birlikte yaşadığı ebeveynin kim olduğu ve ebeveynlerin 
çocukları için profesyonel yardım alma durumunu kapsayan bağımsız değişkenlerin etkisini değerlendirmek amacıyla non-parametrik testlerden "Mann Whitney-U Testr"; çocukların doğum sırası, kardeş sayısı, anne-babanın ayrılığını öğrendikleri kişi, anne-babanın eğitim ve çalışma durumuna göre bağımsız değişkenlerin ikiden fazla grubu içermesi nedeniyle "Kruskal Wallis Testi" kullanılmıştır (Albayrak vd. 2009; Baykul, 1997; Büyüköztürk, 2008; Green vd. 1997).

\section{BULGULAR}

Ebeveynleri boşanma sürecinde olan çocukların boşanmaya uyum düzeylerine ilişkin bulgular tablolar halinde verilmiştir.

Tablo 1: Çocukların cinsiyetine göre boşanmaya uyumlarına ilişkin Mann Whitney-U testi sonuçları

\begin{tabular}{|l|l|l|l|l|l|l|}
\hline Değişken & Cinsiyet & N & $\begin{array}{l}\text { Sıra } \\
\text { Ortalaması }\end{array}$ & $\begin{array}{l}\text { Sıra } \\
\text { Toplamı }\end{array}$ & U & p \\
\hline \multirow{2}{*}{ Boşanmaya Uyum } & Kız & 55 & 49.49 & 2722.00 & \multirow{2}{*}{908.00} & \multirow{2}{*}{0.28} \\
\cline { 2 - 5 } & Erkek & 38 & 43.39 & 1649.00 & \\
\hline
\end{tabular}

Tablo 1 incelendiğinde; yapılan Mann Whitney-U testi sonucunda çocukların cinsiyetine göre boşanmaya uyum ölçeğinden aldıkları puanlar arasında anlamlı bir farklılık olmadığı bulunmuştur $(p>.05)$. $\mathrm{Bu}$ durumda, boşanma sürecinde çocuğun cinsiyetinin uyumu kolaylaştırma ya da zorlaştırma konusunda bir farklılığa neden olmadığı söylenebilir.

Tablo 2: Çocukların doğum sırasına göre boşanmaya uyumlarına ilişkin Kruskal Wallis testi sonuçları

\begin{tabular}{|l|l|c|l|l|c|c|c|}
\hline Değişken & Doğum Sırası & $\mathbf{N}$ & $\begin{array}{l}\text { Sıra } \\
\text { Ortalaması }\end{array}$ & Sd & $\mathbf{x}^{2}$ & $\mathbf{p}$ & $\begin{array}{l}\text { Anlamlılık } \\
\text { Farkı }\end{array}$ \\
\hline \multirow{3}{*}{$\begin{array}{l}\text { Boşanmaya } \\
\text { Uyum }\end{array}$} & İlk çocuk & 48 & 44.09 & & & & \\
\cline { 2 - 4 } & $\begin{array}{l}\text { Ortanca ya da } \\
\text { ortancalardan biri }\end{array}$ & 13 & 70.00 & 2 & 11.11 & 0.004 & $\begin{array}{c}1-2 \\
2-3\end{array}$ \\
\cline { 2 - 4 } & Son çocuk & 32 & 42.02 & & & & \\
\hline
\end{tabular}

Tablo 2 incelendiğinde; yapılan Kruskal Wallis analizi sonucunda çocukların doğum sıralarının boşanmaya uyumlarında anlamlı bir farklılığa neden olduğu görülmektedir $(p<.01)$. Hangi grup ya da gruplar arasında anlamlı farklılık olduğunu anlamak için, bu üç grup arasında ikili Mann Whitney-U testi yapılmıştır. Analiz neticesinde 
ortanca ya da ortancalardan biri olan çocuklarla ilk çocuklar, ayrıca son çocuklar ile ortanca ya da ortancalardan biri olan çocuklar arasında boşanmaya uyum açısından anlamlı bir farklılık olduğu belirlenmiştir. Sonuçta anlamlı farklıığın ortanca ya da ortancalardan birinin uyumunun daha yüksek olması yönünde olduğu tespit edilmiştir.

Tablo 3: Çocukların kardeş sayılarına göre boşanmaya uyumlarına ilişkin Kruskal Wallis testi sonuçları

\begin{tabular}{|l|l|l|l|l|l|l|}
\hline Değişken & Kardeş Sayısı & $\mathbf{N}$ & Sıra Ortalaması & Sd & $\mathbf{x}^{2}$ & $\mathbf{p}$ \\
\hline \multirow{4}{*}{ Boşanmaya Uyum } & Tek çocuk & 22 & 35.36 & & & \\
\cline { 2 - 5 } & 1 kardeş & 42 & 51.43 & \multirow{3}{*}{3} & \multirow{3}{*}{0.09} & 0.25 \\
\cline { 2 - 5 } & 2 kardeş & 25 & 50.24 & & & \\
\cline { 2 - 6 } & 3 ve üstü & 4 & 49.25 & & \\
\hline
\end{tabular}

Tablo 3'te; gerçekleştirilen Kruskal Wallis analizine göre çocukların kardeş sayısına göre boşanmaya uyum ölçeğinden aldıkları puanlar arasında anlamlı bir farklılık olmadığı bulunmuştur (p>.05). Bu durumda kardeş sayısının çocuğun boşanma sürecine uyumunu kolaylaştırma ya da zorlaştırma konusunda bir etkisinin olmadığı ifade edilebilir.

Tablo 4: Çocukların anne-baba ayrılığını öğrendikleri kişiye göre boşanmaya uyumlarına ilişkin Kruskal Wallis testi sonuçları

\begin{tabular}{|l|l|l|l|l|l|l|}
\hline Değişken & $\begin{array}{l}\text { Ebeveyn Ayrılığını } \\
\text { Kimden Öğrendiği }\end{array}$ & $\mathbf{N}$ & Sıra Ortalaması & Sd & $\mathbf{x}^{2}$ & $\mathbf{p}$ \\
\hline \multirow{3}{*}{$\begin{array}{l}\text { Boşanmaya } \\
\text { Uyum }\end{array}$} & Anne & 45 & 45.64 & & & \\
\cline { 2 - 7 } & Baba & 21 & 41.00 & 2 & 2.93 & 0.23 \\
\cline { 2 - 7 } & $\begin{array}{l}\text { Anne ve } \\
\text { baba birlikte }\end{array}$ & 27 & 53.93 & & \\
\hline
\end{tabular}

Tablo 4'te görüldüğü gibi; yapılan Kruskal Wallis analizi sonucuna çocukların anne-baba ayrılığını öğrendikleri kişiye göre boşanmaya uyumlarında anlamlı farklılık olmadığı saptanmıştır ( $p>$.05). Bu sonuca göre, çocuğun ebeveyn ayrılığını anne veya babasından ya da her iki ebeveyninden birlikte öğrenmesinin boşanma sürecine uyumuna etki etmediği ifade edilebilir. 
Tablo 5: Çocukların birlikte yaşadıkları ebeveyne göre boşanmaya uyumlarına ilişkin Mann Whitney-U testi sonuçları

\begin{tabular}{|l|l|l|l|l|l|l|}
\hline Değişken & $\begin{array}{l}\text { Birlikte } \\
\text { Yaşanılan } \\
\text { Kişi }\end{array}$ & $\mathbf{N}$ & $\begin{array}{l}\text { Sıra } \\
\text { Ortalaması }\end{array}$ & $\begin{array}{l}\text { Sıra } \\
\text { Toplamı }\end{array}$ & U & p \\
\hline $\begin{array}{l}\text { Boşanmaya } \\
\text { Uyum }\end{array}$ & Anne & 72 & 45.19 & 3253.50 & 625.50 & 0.23 \\
\cline { 2 - 7 } & Baba & 21 & 53.21 & 1117.50 & 60 \\
\hline
\end{tabular}

Tablo 5'de de görüldüğü gibi; annesi ya da babası ile birlikte yaşayan çocuklar arasında boşanmaya uyum açısından anlamlı bir farklılık olmadığı saptanmıştır ( $p>.05)$. Bu sonuca göre boşanma sürecinde birlikte yaşanılan ebeveynin, çocuğun boşanmaya uyumunu etkileme konusunda bir farklılığa neden olmadığı belirtilebilir.

Tablo 6: Çocukların annelerinin öğrenim düzeyine göre boşanmaya uyumlarına ilişkin Kruskal Wallis testi sonuçları

\begin{tabular}{|c|c|c|c|c|c|c|}
\hline Değişken & $\begin{array}{l}\text { Anne Öğrenim } \\
\text { Düzeyi }\end{array}$ & $\mathbf{N}$ & \begin{tabular}{|l|} 
Sıra \\
Ortalaması
\end{tabular} & Sd & $x^{2}$ & $\mathbf{p}$ \\
\hline \multirow{5}{*}{ Boşanmaya Uyum } & $\begin{array}{l}\text { Okur-yazar, ilkokul } \\
\text { mezunu değil }\end{array}$ & 5 & 51.80 & \multirow{5}{*}{4} & \multirow{5}{*}{5.68} & \multirow{5}{*}{0.23} \\
\hline & İlkokul mezunu & 25 & 49.44 & & & \\
\hline & Ortaokul mezunu & 14 & 32.93 & & & \\
\hline & Lise mezunu & 31 & 52.40 & & & \\
\hline & Üniversite mezunu & 18 & 43.92 & & & \\
\hline
\end{tabular}

Tablo 6 incelendiğinde, yapılan Kruskal Wallis analizine göre annelerin eğitim durumunun, çocukların boşanmaya uyum ölçeğinden aldıkları puanlar üzerinde anlamlı bir farklılık yaratmadığı sonucuna ulaşılmıştır ( $p>.05)$. Bu sonuca göre, annenin eğitim durumunun, çocuğun boşanma sürecine uyumunu etkileme konusunda bir farklıı̆a neden olmadığı ifade edilebilir.

Tablo 7: Çocukların babalarının öğrenim düzeyine göre boşanmaya uyumlarına ilişkin Kruskal Wallis testi sonuçları

\begin{tabular}{|l|l|l|l|l|l|l|}
\hline Değişken & Baba Öğrenim Düzeyi & $\mathbf{N}$ & $\begin{array}{l}\text { Sıra } \\
\text { Ortalaması }\end{array}$ & Sd & $\mathbf{x}^{2}$ & $\mathbf{p}$ \\
\hline \multirow{4}{*}{ Boşanmaya Uyum } & Ilkokul mezunu & 15 & 51.90 & & & \\
\cline { 2 - 4 } & Ortaokul mezunu & 16 & 45.03 & \multirow{3}{*}{0.66} & \multirow{3}{*}{0.88} \\
\cline { 2 - 5 } & Lise mezunu & 43 & 46.78 & & \\
\hline & Üniversite mezunu & 19 & 45.29 & & \\
\hline
\end{tabular}


Tablo 7 incelendiğinde; babaların eğitim durumuna göre çocukların boşanmaya uyum ölçeğinden aldıkları puanlar üzerinden yapılan karşılaştırma sonucunda gruplar arasında anlamlı farklılık olmadığı saptanmıştır ( $p>.05)$. Bu sonuca göre, babanın eğitim durumunun, çocuğun boşanmaya sürecine uyumunu kolaylaştırma ya da zorlaştırma konusunda bir farklıığa yol açmadığı söylenebilir.

Tablo 8: Çocukların annelerinin çalışma durumuna göre boşanmaya uyumlarına ilişkin Kruskal Wallis testi sonuçları

\begin{tabular}{|l|l|l|l|l|l|l|}
\hline Değişken & Anne Çalışma Durumu & $\mathbf{N}$ & Sıra Ortalaması & Sd & $\mathbf{x}^{2}$ & $\mathbf{p}$ \\
\hline \multirow{3}{*}{ Boşanmaya Uyum } & Çalışmıyor & 36 & 47.40 & 2 & 3.71 & 0.15 \\
\cline { 2 - 4 } & Özel sektörde çalışıyor & 42 & 42.62 & & & \\
\cline { 2 - 4 } & Kamu sektöründe çalışıyor & 15 & 58.30 & & \\
\hline
\end{tabular}

Tablo 8 incelendiğinde; yapılan Kruskal Wallis analizine göre, annenin çalışma durumunun, çocukların boşanmaya uyum ölçeğinden aldıkları puanlarda anlamlı bir farklılık yaratmadığı saptanmıştır $(p>.05)$. Sonuç olarak annenin çalışma durumunun, çocuğun boşanmaya uyumunu etkileme konusunda bir farklılığa neden olmadığı belirtilebilir.

Tablo 9: Çocukların babalarının çalışma durumuna göre boşanmaya uyumlarına ilişkin Kruskal Wallis testi sonuçları

\begin{tabular}{|l|l|l|l|l|l|l|}
\hline Değişken & Baba Çalışma Durumu & $\mathbf{N}$ & Sıra Ortalaması & Sd & $\mathbf{x}^{2}$ & $\mathbf{p}$ \\
\hline \multirow{5}{*}{ Boşanmaya Uyum } & Özel sektörde çalışıyor & 44 & 43.34 & & & \\
\cline { 2 - 4 } & $\begin{array}{l}\text { Kamu sektöründe } \\
\text { çalışıyor }\end{array}$ & 23 & 50.33 & \multirow{3}{*}{3} & 2.82 & 0.42 \\
\cline { 2 - 4 } & Kendi işinde çalışıyor & 20 & 46.98 & & & \\
\cline { 2 - 4 } & Emekli & 6 & 61.17 & & & \\
\hline
\end{tabular}

Tablo 9'da babaların çalışma durumuna ilişkin sonuçlar incelendiğinde; babanın çalışma durumunun, çocukların boşanmaya uyumlarında anlamlı farklııı yaratmadığı sonucuna ulaşılmıştır ( $p>$.05). Babalardaki emeklilik durumunun, annelerdeki çalışmama hali ile benzerlik gösterdiği ve emekli olmanın da çocuğun boşanmaya uyum düzeyinde anlamlı etki yaratmadığı dikkate alındığında elde edilen bulguların Tablo 8'deki sonuçlar ile paralellik gösterdiği ve araştırma bulgularının birbirini destekler nitelikte olduğu düşünülmektedir. 
Tablo 10: Çocukların profesyonel yardım alma durumuna göre boşanmaya uyumlarına ilişkin Mann Whitney-U testi sonuçları

\begin{tabular}{|l|l|l|l|l|l|l|}
\hline \multirow{2}{*}{ Değişken } & $\begin{array}{l}\text { Profesyonel } \\
\text { Yardım Alma } \\
\text { Durumu }\end{array}$ & $\mathbf{N}$ & $\begin{array}{l}\text { Sıra } \\
\text { Ortalaması }\end{array}$ & $\begin{array}{l}\text { Sıra } \\
\text { Toplamı }\end{array}$ & U & $\mathbf{p}$ \\
\hline $\begin{array}{l}\text { Boşanmaya } \\
\text { Uyum }\end{array}$ & Evet & 18 & 45.28 & 815.00 & 644.00 & 0.76 \\
\cline { 2 - 7 } & Hayır & 75 & 47.41 & 3556.00 & 600 \\
\hline
\end{tabular}

Tablo 10 incelendiğinde; gerçekleştirilen Mann Whitney-U analizi sonucunda çocukların profesyonel yardım alma durumuna göre boşanmaya uyum ölçeğinden aldıkları puanlar arasında anlamlı bir fark olmadığı bulunmuştur ( $p>.05)$. Bu durumda boşanma sürecinde çocukların profesyonel yardım alma durumunun boşanmaya uyumlarında anlamlı bir farklılığa neden olmadığı ifade edilebilir.

\section{TARTIŞMA}

Ebeveynleri boşanma sürecinde olan dokuz-on iki yaş grubundaki çocuklarla gerçekleştirilen araştırmada; çocukların boşanmaya uyumunda doğum sırasının anlamlı farklıığa sebep olduğu belirlenirken, çocukların cinsiyetinin, kardeş sayısının, annebaba ayrılığını öğrendiği kişinin, birlikte yaşadığı ebeveynin kim olduğunun, anne-babanın öğrenim düzeyinin, çalışma durumunun ve çocuk için profesyonel yardım alınmasının anlamlı bir farlılık yaratmadığı saptanmıştır.

Tablo 1'de çocukların cinsiyetine göre boşanmaya uyum ölçeğinden aldıkları puanlar arasında anlamlı bir farklılık olmadığı bulunmuştur. Boşanma sürecinde bulunan çocukların iki ebeveynden birisini tercih etmek zorunda bırakılmasının gerek kız, gerekse erkek çocuklar üzerinde yoğun duygusal baskı yarattığı, bu durumun da cinsiyetler arasındaki farklılığın etkilerinin, boşanmaya uyum noktasında ortaya çıkmasını engellediği düşünülmektedir. Literatür incelendiğinde kız çocuklarının boşanmadan daha fazla etkilendiğini ortaya çıkaran araştırma bulguları olduğu gibi, erkek çocuklarının boşanmadan daha fazla olumsuz etkilendiğini ve ebeveynlerinin boşanmasına kızlara göre daha zor uyum sağladıklarını belirten araştırma bulguları da bulunmaktadır. Neher ve Short (1998) boşanmış ebeveynlerin çocukları ile gerçekleştirdikleri çalışmalarında, parçalanmış ailelerden gelen kız çocuklarının, erkek çocuklarına göre daha fazla sosyal uyumsuzluk belirtileri gösterdiğini ortaya çıkarmışlardır. Cummings vd. (1994) çalışmalarında, kız çocuklarının erkek çocuklarına göre boşanmaya daha zor uyum sağladıkları, 
kızların ebeveyn ayrılığından dolayı kendilerini suçlamaları nedeniyle boşanmaya uyumlarının zorlaştığı, erkek çocuklarının daha dışa dönük yapıda olmalarının ve başetme kapasitelerinin yüksekliğinin uyum farklıı̆̆ını artıran temel nedenler olduğunu belirtilmişlerdir. Amato (2000) parçalanmış ailelerden gelen çocukları kendi içlerinde, ayrıca tam ailelerde yaşayan çocuklar ile akademik başarı, psikososyal uyum, kendine güven ve sosyal ilişki başarısı açısından karşılaştırdığı çalışmasında, boşanmış ailelerden gelen erkek çocukların, kız çocuklarına göre daha fazla uyum problemi gösterdiklerini ortaya çıkarmıştır. Aral ve Gürsoy (2000) ebeveynleri boşanmış ve boşanmamış çocukların depresyon düzeyini karşılaştırmayı amaçladıkları çalışmalarında; parçalanmış ailelerden gelen erkek çocukların, kız çocuklara göre depresyon düzeylerinin yüksek olduğu sonucuna ulaşmış, erkek çocukların boşanma olayından daha fazla olumsuz etkilendiklerini belirtmişlerdir.

Çocukların doğum sıralarının boşanmaya uyumlarında anlamlı bir farklılığa neden olduğu görülmektedir (Tablo 2). İlk çocuklar evliliğin başlangıç yıllarına rastlar ve büyük bir sevgi, aynı zamanda ilgiyle büyürler. Ayrıca ebeveynlerin bu çocuk ile ilgili beklentileri yüksektir. En küçük çocuk ise her yaşta evin küçüğü olarak algılanır ve en küçük olmanın bütün önceliklerinden yararlanır. Ortanca çocuğun ise durumu daha karmaşıktır. İlk çocuk üzerindeki aşırı ilgi ve sevgi ile doğru orantılı olan yüksek beklenti düzeyi ortanca çocuklarda azalır. $\mathrm{Bu}$ çocuklar çevreye daha kolay uyum sağlayarak, daha çabuk arkadaş edinebilirler ve daha girişken olabilirler. İlk ve son çocuğa göre daha az kollanabildiklerinden kendi doğrultularında gelişme olanağı bulabilme imkanları yüksektir. Ebeveynlerinden çeşitli nedenlerle gördükleri sevginin azalması, üzerlerindeki ilginin farklı yönlere kayması, ortanca çocuklara göre, ilk ve son çocukları daha fazla olumsuz etkileyebilmektedir (Yörükoğlu, 2003).

Tablo 3'te çocukların kardeş sayısına göre boşanmaya uyum ölçeğinden aldıkları puanlar arasında anlamlı bir farklılık olmadığı saptanmıştır. Boşanma nedeniyle kardeşlerin ayrılmamış olması, çocukların ebeveyn boşanması ile beraber, bir de kardeş ayrılığı yaşamamaları önemli olmakla birlikte, kardeşin varlığı boşanma sürecinde çocuğun uyumu üzerinde olumlu veya olumsuz bir etki yapmamaktadır. Bunun en temel nedeni çocuğun bu süreçte daha fazla kendisini düşünmesi ve kendi iç dünyasına yoğunlaşmasıdır. Ancak kardeşler arasındaki yaş farkı fazlaysa, büyük çocuk küçük kardeşi için önemli bir sosyal destek sistemi olabilme potansiyeli taşımaktadır (Öztürk, 2008). Arifoğlu (2006) çalışmasında, boşanmış çiftlerin çocuklarının kardeş sayılarının boşanmaya uyumları üzerinde 
önemli bir etkiye sahip olmadığını tespit etmiştir. Bu sonuç, araştırmada elde edilen bulguları destekler niteliktedir.

Çocukların anne-baba ayrılığını öğrendikleri kişiye göre boşanmaya uyumlarında anlamlı farklılık olmadığı Tablo 4'te görülmektedir. Boşanma kararı alan ebeveynlerin, bu durumu birlikte ve çocuğun yaşına uygun şekilde çocuğa anlatmaları, çocuğun ebeveyn ayrılığını daha kolay ve hızlı bir şekilde kabullenerek, annebaba ayrılığına ve yeni yaşam düzenine uyumuna olumlu etki eden durumlardan birisidir (Benedek ve Brown, 1997; Öztürk, 2008). Araştırma kapsamında ebeveyn ayrıı̆̆ını anne ve babasından birlikte öğrenen çocukların, bu durumu anne veya babadan birisinden öğrenen çocuklara göre boşanmaya uyumlarının yüksek çıkmamasında; ilk zamanlarda ayrılık kararını çocuğa birlikte açıklayarak sorumlu davranan bu ebeveynlerin, boşanma sürecinde diğer ebeveynler gibi çocuğu anne-baba arasında velayet konusunda tercih yapmak zorunda bırakmalarından kaynaklandığı düşünülmektedir.

Araştırmada annesi ya da babası ile birlikte yaşayan çocuklar arasında boşanmaya uyum açısından anlamlı bir farklılık olmadığı saptanmıştır (Tablo 5). Boşanma süreci, yetişkinler ve çocuklar açısından içerisinde çeşitli belirsizlikleri barındıran bir dönemdir. Yetişkinlerin ebeveynlik rollerini ihmal edebildikleri boşanma sürecinde, çocuk ve ebeveyn arasındaki ilişkinin niteliğinin olumsuz anlamda farklılaşması, diğer yandan çocuk istediği ebeveyni ile kalıyor olsa bile, gelecekte bu durumun değişebileceği kaygısı boşanmaya uyumu zorlaştırabilmektedir. Ayrıca çocukların yaşadıkları ebeveyne göre boşanma sürecine uyumlarının farklılaşmamasında, dava sürecinde velayet konusunda ebeveynler arasında tercih yapma zorunluluğu içerisinde bırakılmalarının da etken olduğu düşünülmektedir. Boşanma süreci yaşayan kadınlarda duygusal ve psikolojik semptomlar görülebilmektedir. Bu olumsuz duygu durumu, yaşanan ekonomik kaygılar ve gelecek belirsizliği ile birleşince annelerin ebeveynlik yeteneği azalabilmekte ve bu durum çocuklara yansıyabilmektedir (Amato ve Previti, 2003). Amato (2000) boşanma sürecinde ve sonrasında ebeveyn uyuşmazlığı ile çatışması arasında kalan, ayrıca taraf tutmaya zorlanan çocuğun boşanmaya uyumunun zorlaştığını belirtmektedir. Aral ve Gürsoy (2000) gerçekleştirdikleri çalışmalarında, parçalanmış ailelerden gelen çocukların, birlikte yaşadıkları ebeveyne göre depresyon düzeyleri arasında anlamlı bir farklılık olmadığını saptamışlardır. Whiteside ve Becker (2000) çalışmalarında, annenin çocuğu ile ilişkisinin kaliteli 
olmasının çocuğun davranış problemlerini azalttığını, aynı zamanda çocuğun boşanmaya uyumunu artırdığını ortaya çıkarmışlardır.

Tablo 6 ve Tablo 7'de anne-babanın öğrenim düzeyine göre çocukların boşanmaya uyum ölçeğinden aldıkları puanlar üzerinden yapılan karşılaştırma sonucunda anlamlı farklılık olmadığı saptanmıştır. Boşanma sürecinde anlaşmazlık yaşayan çiftlerin üzerlerindeki yoğun duygusal baskının, eğitim seviyesinin davranışlarda yaratması beklenen olumlu durumları engelleyebildiği, çünkü bu süreçte kişilerin bilişsel yapılardan çok, duygularının etkisi ile davranışlarını biçimlendirdikleri düşünülmektedir. Boşanma sürecinde beklenen, boşanma gerçeği ile karşı karşıya kalan yetişkinlerin, evlenme gibi boşanmanın da yaşanabilecek doğal bir olgu olduğunu kabul etmeleridir. Boşanma gerçeğini kabul eden yetişkinler, evlilik içinde yaşadıkları sorunlar nedeniyle kendilerini etkisi altına alabilecek olumsuz duygular ile değil, mantığa dayalı düşünceleri ile dava süreçlerini ve günlük yaşantılarını sürdürebilirler. Fakat boşanma sürecinde özellikle velayet, nafaka, tazminat gibi konularda ortaya çıkan sorunlar nedeniyle, yaşadıkları problemler daha da artan yetişkinler, bireysel özellikleri ne olursa olsun çeşitli düzeylerde olumsuz duygu durumlarının etkisinde kalabilmektedirler. $\mathrm{Bu}$ durumun araştırmaya alınan anneler ve babalar üzerinde de etkisini gösterdiği; annelerin ve babaların kendi içlerindeki eğitim farkının çocukların boşanmaya uyumları üzerinde farklılık yaratmaması sonucunu doğurduğu düşünülmektedir. Ebeveynlerin, boşanmanın da evlenme gibi zaman gerektiren bir süreç olduğunu ve ayrılığın tamamlanmasının, mahkeme işlemlerinden daha uzun bir süreç olduğunu en başta kabullenmeleri gerekir. Bu kabul sonucu yetişkinler, bireysel özelliklerini de ön plana çıkararak çocukları ile sağlıklı iletişim kurup, çocukların boşanmaya uyumunu kolaylaştırabilirler (Yazgan ve Yazgan, 2005). Neher ve Short (1998) ebeveynleri boşanmış olan çocuklar ile gerçekleştirdikleri çalışmalarında, babanın eğitim düzeyi ile parçalanmış ailelerden gelen çocukların gösterdikleri davranış problemleri arasında korelasyon olmadığı sonucunu ortaya çıkarmışlardır.

Annenin ve babanın çalışma durumunun, çocukların boşanmaya uyum ölçeğinden aldıkları puanlar üzerinde anlamlı farkılıı yaratmadığı Tablo 8 ve Tablo 9'da görülmektedir. Parçalanmış ailelerde yaşayan çocukların, ebeveynlerinin gelirinin düzenli olması, ayrıca gelir yüksekliği, çocuğa daha fazla sosyal imkan sağlama fırsatı sunduğundan, çocuğun kendisini daha rahat ifade edebilmesinin yolunu açarak, çocuğun boşanmaya uyumunu kolaylaştırmaktadır (Stewart vd., 2000). Bununla birlikte özellikle evlilik birliği içerisinde çalışmayan kadının, boşanma sürecinde ve 
sonrasında çalışmak zorunda kalması sebebiyle, gelirin sürekliliği sağlanmasına rağmen, ebeveynlik rolünü yerine getirirken zorlanma intimali çocuğun örselenmesinin yolunu açabilmektedir (Yörükoğlu, 2003). Baran ve Bütün Ayhan (2004) çalışmalarında, annenin çalışma durumunun çocukların bağımlılık eğilimleri üzerinde anlamlı bir farklılık yaratmadığı sonucuna ulaşmış, annenin çalışma durumundan çok, çocuğu ile kurduğu ilişkisinin niteliğinin önemli olduğu vurgulanmıştır. Arifoğlu (2006) çalışmasında, annelerin gelir düzeyinin çocukların boşanmaya uyumlarında önemli bir etkiye sahip olmadığını ortaya çıkarmıştır. Bu sonucun, araştırma bulgularını destekler nitelikte olduğu düşünülmektedir.

Tablo 10'da çocukların profesyonel yardım alma durumuna göre boşanmaya uyum ölçeğinden aldıkları puanlar arasında anlamlı bir fark olmadığı görülmektedir. Boşanma sürecinde sadece ebeveynleri arasındaki velayet anlaşmazlığı arasında kalan çocuklar için değil, parçalanma sürecini yaşayan tüm aile bireyleri için profesyonel yardım verilmesiyle, çocukların ebeveyn ayrılığını kabul etmeleri kolaylaşabilir ve yeni yaşamlarına uyum sağlamada daha az zorluk yaşayabilirler. Bununla birlikte profesyonel yardım alan çocuklar ile bu desteği alamayan çocukların uyum puanlarında fark olmamasının, her iki gruptaki çocukların da boşanma sürecinde ebeveynleri tarafından taraf tutmaya ve velayet konusunda tercih yapmaya zorlanmalarından kaynaklandığı düşünülmektedir. Boşanma sürecinde önemli olan çocuğun ebeveynler arasında yan tutmaya zorlanmamasıdır. Ebeveynlerin kendi haklılıklarını ispat etmek için çocuk üzerinde baskı kurmaları, çocuğun gelişimi açısından olumsuz etki yaratabilir. Bu nedenle boşanma sürecinde ebeveynler arasındaki uzlaşmazlık sebebiyle olumsuz etki altında kalan çocuklar için, bu sorumluluk sadece ebeveynlere bırakılmamalı, mahkemeler de profesyonel meslek elemanlarından destek istemelidirler (Benedek ve Brown, 1997). Parçalanmış ailelerden gelen kimi çocuklar ebeveyn ayrılığına daha kolay uyum sağlarken, ebeveyn uzlaşmazlığını yoğun olarak yaşayan, taraf tutmaya zorlanan ve boşanma sürecine ebeveynleri tarafından hazırlanmayan çocuklarda kimi tepkiler normal sınırları aşıp ruhsal, duygusal ve sosyal anlamda sorun haline gelebilmektedir. Depresyon, kaygı, uyku bozuklukları, okul sorunları, davranış bozuklukları gibi geniş bir yelpazede görülebilecek bu sorunlarda mutlaka profesyonel meslek elemanlarından destek alınmalıdır. Bu durum çocuğun boşanmaya uyumunu kolaylaştırmada önemli etkenlerden birisi olma potansiyeline sahiptir (Öztürk, 2008). Arifoğlu (2006) çalışmasında, boşanmaya uyum programına katılan çocukların, boşanmaya uyum konusunda aldıkları öntest ve sontest 
puanları arasında anlamlı bir farklılık olduğu, programa katılan çocukların boşanmaya uyumlarının yükseldiği sonucuna ulaşmıştır.

\section{SONUÇ VE ÖNERILER}

Araştırmaya dahil edilen çocukların boşanmaya uyumlarında; cinsiyetin, kardeş sayısının, anne-baba ayrılığını öğrendiği kişinin, birlikte yaşadığı ebeveynin kim olduğunun, anne-babanın öğrenim düzeyinin, anne-babanın çalışma durumunun ve çocuk için profesyonel yardım alınmasının anlamlı bir farlılık yaratmadığı ( $p>.05)$, yalnızca çocuğun doğum sırasının boşanmaya uyumda anlamlı bir farklılığa neden olduğu $(p<.01)$ belirlenmiştir.

Araştırmaya alınan çocukların yalnızca doğum sıralarının boşanmaya uyumlarını etkilediği, bunun dışındaki değişkenlerin çocukların boşanmaya uyumunda anlamlı farklılığa yol açmadığı, çocukların ebeveynlerinin boşanma sürecinde olmasından olumsuz etkilendiği sonucuna ulaşılmıştır. Boşanma kararı alan ebeveynlerin, çocuklar ile ilgili konularda uzlaşmazlık yaşayarak, çocukları dava sürecinde tercih yapmak zorunda bırakmamaları için, yazılı ve görsel kitle iletişim araçları vasıtasıyla ve akademik çalışmalarla toplum bilinçlendirilmelidir. Alınan tüm önlemlere rağmen boşanma sürecinde çocuk ile ilgili konularda uzlaşmazlık yaşamaya devam ederek çocuklarının gelişimine zarar veren ebeveynler dava süresince annebaba eğitim programlarına dahil edilmelidir. Bu şekilde, ebeveynlerin çocukların doğum sırasına göre küçüklere sevgi aktarması veya duygusal yüklemede bulunmalarının önüne geçilmeye çalışılmalıdır.

Ebeveynlerinin yaşadığı uzlaşmazlık nedeniyle boşanma davası sürecinde etkin olarak bulunmak zorunda kalan çocuklara psikolojik destek ve sağaltım hizmetleri devlet eliyle ücretsiz olarak verilmelidir.

Aile mahkemelerinde çocuklar ile yapılacak çalışmalarda daha işlevsel sonuçlar elde edilebilmesi için uzman grubunda çocuk gelişim uzmanları da yer almalıdır. Boşanmanın bir süreç olduğu düşüncesinden hareketle, boşanma sonrasında da çocuklar için destekleyici hizmetler gerçekleştirilmelidir.

Alınacak tüm önlemler ile sağlıklı evlilikler yapan kişilerin mutlu olup, gelişimin tüm yönlerini sağlıklı olarak yaşayabilecek çocuklar yetiştirebilecekleri, aynı şekilde aile parçalanması yaşamalarına rağmen sorunları çocukların uyum düzeylerinin artacağı unutulmamalıdır. 


\section{KAYNAKLAR}

Albayrak, S. A., Eroğlu. A., Kalaycı, Ş., Küçüksille, E., Ak, B., Karaatlı, M., Ünlü, H., Çiçek, E., Kayış, A., Öztürk, E., Antalyalı, Ö.L., Uçar, N., Demirgil, N., İşler, D. ve Sungur, O. (2009). SPSS uygulamalı çok değişkenli istatistik teknikleri. Asil Yayınevi, Ankara.

Amato, P. R. (2000). The consequences of divorce for adults and children. Journal of Marriage and the Family, 62, 1269-1287.

Amato, P. R. and Previti, D. (2003). People's reosons for divorcing: Gender, social class, the life course and adjustment. Journal of Family Issues, 24, 602-626.

Aral, N. ve Başar, F. (1998). Çocukların kaygı düzeylerinin yaş, cinsiyet, sosyo-ekonomik düzey ve ailenin parçalanma durumuna göre incelenmesi. Eğitim ve Bilim, 22, 7-12.

Aral, N. ve Gürsoy, F. (2000). Boşanmış ve boşanmamış ebeveynlerin çocuklarının depresyon düzeyleri üzerine bir araştırma. Toplum ve Sosyal Hizmet, 1, 18-28.

Arifoğlu, Ç. B. (2006). Çocuklar için boşanmaya uyum programının, çocukların boşanmaya uyum, kaygı ve depresyon düzeylerine etkisi. Doktora tezi (Basılmamış), Hacettepe Üniversitesi, Sağlık Bilimleri Enstitüsü, Ankara.

Baran, G. ve Bütün Ayhan, A. (2004). Parçalanmış ve tam ailelerden gelen 9-11 yaş grubundaki çocukların bağımlılık eğilimlerinin incelenmesi. Mesleki Eğitim Dergisi, 6, 85-100.

Baykul, Y. (1997). İstatistik metodlar ve uygulamalar. Anı Yayıncılık, Ankara.

Beardslee, W. R., Tracy, G. R., Gladstone, G., Ellen, J. and Cooper, A. B. (2003). A family based approach to prevention of depressive symptoms in children at risk: evidence of parental and child change. Offical Journal of the American Academy of Pediatrics, 112, 119-131.

Benedek, E. P. and Brown, C. F. (1997). Boşanma ve çocuğunuz: Çocuğunuzun boşanmanızla baş etmesine nasıl yardımcı olursunuz (Çev: Serap Katlan). HYB Yayıncılık, Ankara.

Büyüköztürk, Ş. (2008). Sosyal bilimler için veri analizi el kitabı. Pegem Yayıncılık, Ankara. 
Cohen, J. G. (2002). Helping children and families deal with divorce and seperation. Official Journal of the American Academy of Pediatrics, 110, 1019-1023.

Cummings, E. M., Davies, P. T. and Simpson, K. S. (1994). Marital conflict, gender and children's appraisals and coping efficacy as mediators of child adjustment. Journal of Family Psychology, 8, 141-149.

Emery, R. E., Waldron, M., Kitzmann, K. M. and Aaron, J. (1999). Delinquent behavior, future divorce or nonmarital childbearing and externalizing behavior among offspring: A 14 year prospective study. Journal of Family Psychology, 13, 568-579.

Green, S.B., Salkind, N.J. and Akey, T.M. (1997). Using SPSS for windows: Analyzing and understanding data. Prentice Hall, New Jersey.

Hawkins, J. D., Catalano, R. F. and Miller, J. Y. (1992). Risk and protective factors for alcohol and other drug problems in adolescence and early adulthood: Implicants for substance abuse preventetion. Psychological Bulletin, 112, 64-105.

Korkut, Y. (1990). Adolescent from divorced home: A comparison of family status and an investigation of some factors related to self concept and depression. Master thesis (Unpublished), Boğaziçi University, Institue of Social Sciencies, İstanbul.

Kuyucu, Y. (1999). Ana-babaları boşanmış ve birlikte yaşayan lise öğrencilerinin uyum sorunlarının karşılaştırılması. Yüksek lisans tezi (Basılmamış), Dokuz Eylül Üniversitesi, Eğitim Bilimleri Enstitüsü, İzmir.

Lengua, L. S. (2000). The additive and interactive effects of parenting and temparement in predicting adjustment problems of children of divorce. Journal of Clinical Child Psychology, 29, 232-244.

Mechanic, D. and Hansell, P. (1989). Divorce, family conflict and adolescents' well-being. Journal of Health and Social Behavior, 30, 105-116.

Neher, L. S. and Short, L. J. (1998). Risk and protective factors for childrens' substance use and antisocial behavior following parental divorce. American Journal of Orthopsychiatry, 68, 154162.

O'Connor, T. G., Caspi, A., Detries, J. C. and Plomin, R. (2000). Are associations between parental divorce and childrens' adjustment 
genetically mediated. American Psychological Association, 36, 429-437.

Öztürk, S. (2006). Anne-babası boşanmış 9-13 yaşlarındaki çocuklar ile aynı yaş grubundaki anne-babası boşanmamış çocukların benlik saygısı ve kaygı düzeyleri ilişkisi. Yüksek lisans tezi (Basılmamış), Dokuz Eylül Üniversitesi, Eğitim Bilimleri Enstitüsü, İzmir.

Öztürk, M. (2008). 99 sayfada boşanmış ailelerde çocuk. Türkiye İş Bankası Kültür Yayınları, İstanbul.

Portes, P.R., Lehman, A.J., and Brown, J. H. (1999). The child adjustment inventory: Assessing transition in child divorce adjustment. Divorce \& Remarriage, 30, 37-45.

Salk, L. (2002). Bebeklikten yetişkinliğe çocuğun duygusal sorunları (Çev: Erzem Onur). Remzi Kitabevi, İstanbul.

Stewart, A. C., Vandell, D. L., Mc.Cartney, K., Owen, M.T. and Booth, C. (2000). Effects of parental seperation and divorce on very young children. Journal of Family Psychology, 14, 304-326.

Yazgan, Y. ve Yazgan, Ş. (2005). 250 soruda çocuk büyütmek. Milliyet Yayınları, İstanbul.

Yörükoğlu, A. (2003). Çocuk ruh sağlığı: Çocuğun kişilik gelişimi, eğitimi ve ruhsal sorunları. Özgür Yayınları, İstanbul.

Walczak, Y. and Burns, S. (2004). Boşanma ve çocuk üzerine etkileri (Çev: İsmail Ersevim). Özgür Yayınları, İstanbul.

Whiteside, M. F. and Becker, B. J. (2000). Parental factors and young child's postdivorce adjustment: A meta-analysis with implications for parenting arragements. Journal of Family Psychology, 14, 526. 
